\title{
Relationship between Red Tide Occurrences in Four Japanese Bays and Dam Construction
}

\author{
Kunio Ue da \\ Department of Biological Resources Management, School of Environmental Science, The University of Shiga Prefecture, Japan
}

\begin{abstract}
Since about half a century ago, red tide has been occurring in many coastal places of Japan, such as Tokyo Bay, Ise Bay, Osaka Bay, and Ariake Sea. Red tide is algal accumulation that could be a result of eutrophication in bays and lakes. At the same time, dams have been constructed in Japan on rivers that flow into the bays where red tide has been occurring. The correlation between red tide occurrence and dam construction in Japan was researched using the data of many government organizations. The results indicate that the construction of dams influences the occurrences of red tide. When a dam is built on a river, there is a tendency for red tide to result in an estuary of that river a few years later. The number of red tide occurrences is related to the surface area of the dam: as the surface a rea of a constructed dam increases, the number of red tide occurrences in a bay increases. Thus, the construction of dams seems to cause eutrophication in bays and lakes. Because it seemed that small particles flowed from dams contain nutrients that stimu late the growth of algae.
\end{abstract}

Keywords Red Tide, Dam, Construction, Coastal Area, Surface Area, Estuary

\section{Introduction}

Red tides have been occurring in bodies of water worldwide for many decades. Red tides are caused by eutrophication and other factors such as ocean currents. Untreated sewage effluent and agricultural run-off increase levels of nutrients in bodies of water and could cause great increases in phytoplankton, creating red tides. Red tides are sometimes associated with the production of toxins and depletion of dissolved oxygen. In these cases, red tides are connected with wildlife mortalities of coastal species of fish and marine animals.

In Japan, red tides have been occurring in areas of the sea, especially in bays such as Ise Bay, Tokyo Bay, Osaka Bay, Ariake Sea, Sendai Bay, and Toyama Bay.

Sewage treatment must be improved to remove nutrients from sewers. Starting about 30 years ago, the Japanese government has made efforts to develop sewage treatment in almost all areas, especially in cities that exist around the bays discussed in this paper. Sewage treatment is greater than $80 \%$ in these cities. Agricultural workers have been advised to use fertilizers minimally in cultivating crops. However, red tide occurrences have not stopped yet in Japan. On the other hand, red tide may be caused not only by eutrophication for which people are responsible but also by other factors related to ocean currents reported by Trainer et al. and Adams et al.[1,2].

* Corresponding author:

ueda@ses.usp.ac.jp (Kunio Ueda)

Published online at http://journal.sapub.org/env

Copyright (C) 2012 Scientific \& Academic Publishing. All Rights Reserved
In these cases, other factors should be discussed for solving the problem of red tide occurrence.

One of these factors may be dam construction on inflowing rivers. The relationship between dam construction and the occurrence of red tide has not yet been studied. I researched the effect of dam construction on red tide occurrences in Japan and the results are reported here.

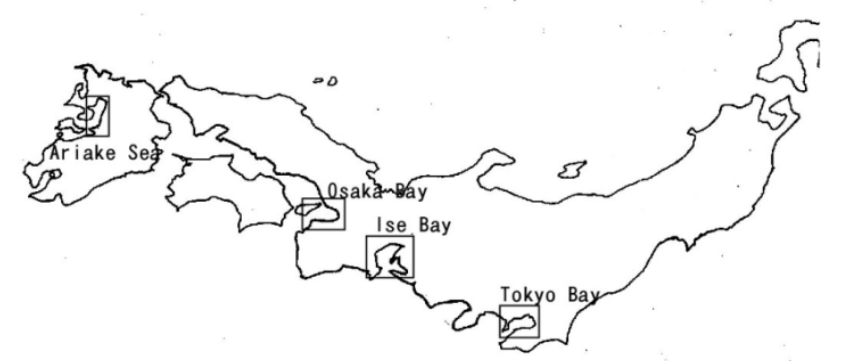

Figure 1. The four Japanese bays studied in this paper

\section{Materials and Methods}

Ariake Sea, Tokyo Bay, Ise Bay, and Osaka Bay were researched in this report. I obtained the information about dams in Japan from a website offered by The Japan Dam Foundation[3]. The number of red tide occurrences in Ariake Sea was obtained from a website created and maintained by the Japan Fisheries Resource Conservation Association[4], and the locations of red tides were obtained from a website created and maintained by Seikai National Fisheries Research Institute, Fisheries Research Agency[5]. The number of red tide occurrences in Tokyo Bay was obtained from a website offered and maintained by the Kanto 
Regional Development Bureau, Ministry of Land, Infrastructure, Transport, and Touris $\mathrm{m}[6]$. The locations of red tide occurrences in Tokyo Bay were obtained from the website of the Environmental Bureau of Tokyo Metropolitan Government[7] and the website of the Environmental Institute of Yokohama City[8]. Information about red tide occurrences in Ise Bay was obtained from the Ise Environmental Database (a website created and maintained by the Port and Airport Department, Chubu Regional Bureau, Ministry of Land, Infrastructure and Transport and Tourism [9]). The locations of red tide occurrences in Ise Bay were obtained from the website of the Aichi Prefectural Fisheries Experimental Station[10]. The information about red tide occurrences in Osaka Bay was obtained from a website created and maintained by the Air and Water Environment Management Division, Min istry of the Environment[11].

\section{Results and Discussion}

\subsection{Ariake Sea}

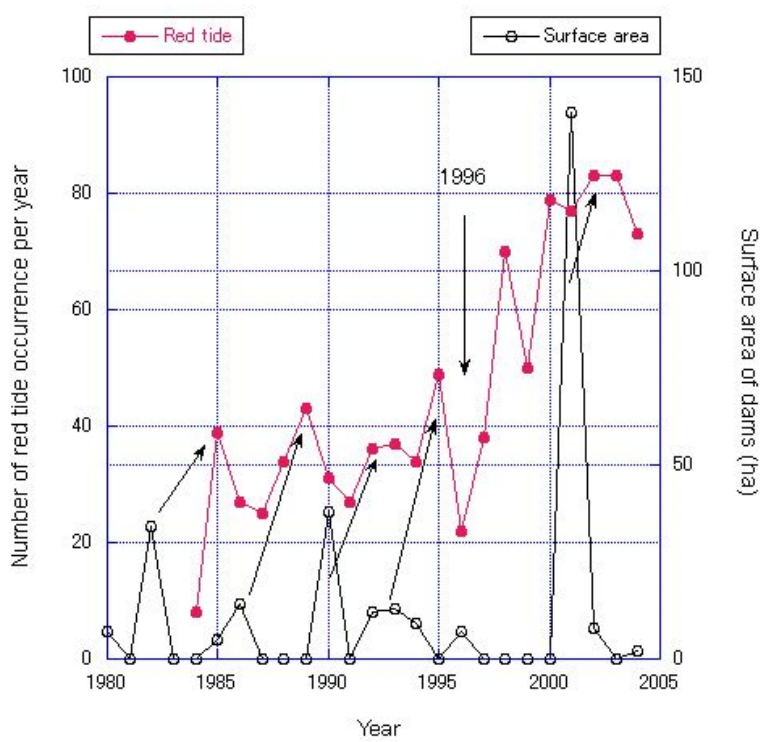

Figure 2. The relationship bet ween the number of red tide occurrences per year in the Ariake Sea and the surface area of dams built on theriver flowing into the Ariake Sea. Arrows show the correlations between dam construction and the number of red tide occurrences

Figure 2 shows the correlation between the number of red tide occurrence in the Ariake Sea and the surface area of dams built on rivers that flow into the Ariake Sea. In 1982, three dams with a total surface area of 34 ha were built on rivers that flow into the Ariake Sea. As suggested in Figure 2, the dam built in 1982 was considered to bring about the increasing number of red tide occurrences in 1985. The Chikugo estuarial barrier dam with a 136-ha surface area was built in 1984 on the Chikugo River and the Tenzan Dam with a 14-ha surface area was built on the Rokkaku River. These two dams were considered to be a cause of the increasing number of red tide occurrences from 1988 to 1990. In the same way, the Gousho Dam completed on the Chikugo River in 1990 increased the number of red tide occurrences from 1992 to 1994. In 1993, the Yahazu Dam and in 1994, the Niwaki Dam were built on the Rokkaku River. These two dams increased the number of red tide occurrences in 1995.

From 1991 to 1999, no dam was built on the river that flows into the Ariake Sea except for small two dams, but the number of red tide occurrences has been increasing drastically from 1997. In 1996, the Isahaya Bay dike was completed. It appears that the red tide occurrences after 1997 were brought about by the Isahaya Bay dike. Generally, the floodgates of the Isahaya Bay dike are very similar to dams built on rivers. The floodgates are opened at a low tide and release the upper portion of stored water from behind the dike. Usually, the upper portion of water contains high concentration of small particles of soil or clay.

These results suggest a clear correlation between red tide occurrence and dam construction. In the Ariake Sea, the locations of red tide occurrences were recorded from 2004, as shown in Figure 3. In 2001, the Ryumon Dam with a surface area of 121 ha was built in the Kikuchi River and red tides occurred offshore of its estuary and on the north or south sides of the estuary. These red tides were considered to be brought about by the construction of the Ryumon Dam. In these cases, red tides were thought to have migrated from an estuary of the Kikuchi River to the north or south by tidal currents in the bay carrying muddy soil. Algae grew and accumulated in the deposited muddy soil, and then floated free to become a red tide.

The Yokotake Dam with a 20-ha surface area was also built on the Shiota River in 2001 and red tide occurrences were observed near an estuary of the river (Fig. 3). When the numbers of red tide occurrences brought about by the Ryumon Dam and the Shiota Dam were compared, their numbers were thought to be correlated with the surface areas of the dams. The number of red tide occurrences appears to be proportional to the dam surface area. The area of red tide occurrences also has the same tendency (Fig. 3).

In 2000, the Hujinami Dam was completed on the Chikugo River. Its surface area was 74 ha. In the estuary of the Chikugo River, a red tide occurred that was thought to have been brought about by the Hujinami Dam (Fig. 3).

\subsection{Tok yo Bay}

Figure 4 shows that in Tokyo Bay, there is the correlation between dam completion and red tide occurrence. Each arrow in Figure 4 indicates that the dam brought about the red tides. Rivers that flow into Tokyo Bay are shown in Figure 5. Figure 4 shows that 2 or 3 years after the dams were built, the number of red tide occurrences increased in almost all cases.

On the Kohitu River, the Kameyama Dam was completed in 1980 and was considered to bring about red tides 2 years later. On the Tone River, the Tambara Dam in 1981 and the Kiryugawa Dam in 1982 were completed and they were thought to increase the number of red tide occurrences 2-3 years later. The Tone River flows into Tokyo Bay through 
the Edogawa River. On the Arakawa River, the Arima Dam was constructed and completed in 1985 and is thought to have brought about red tide occurrences observed in 1986. From 1980 to 1985, as shown in Figure 4, the number of red tide occurrences increased when the surface area of a dam increased.

In 1990, two big dams were built on the river flowing into Tokyo Bay. One of them is the Naramata Dam with a 200-ha surface area. It was built on the Tone River. The other one is the Takataki Dam with a 199-ha surface area. It was built on

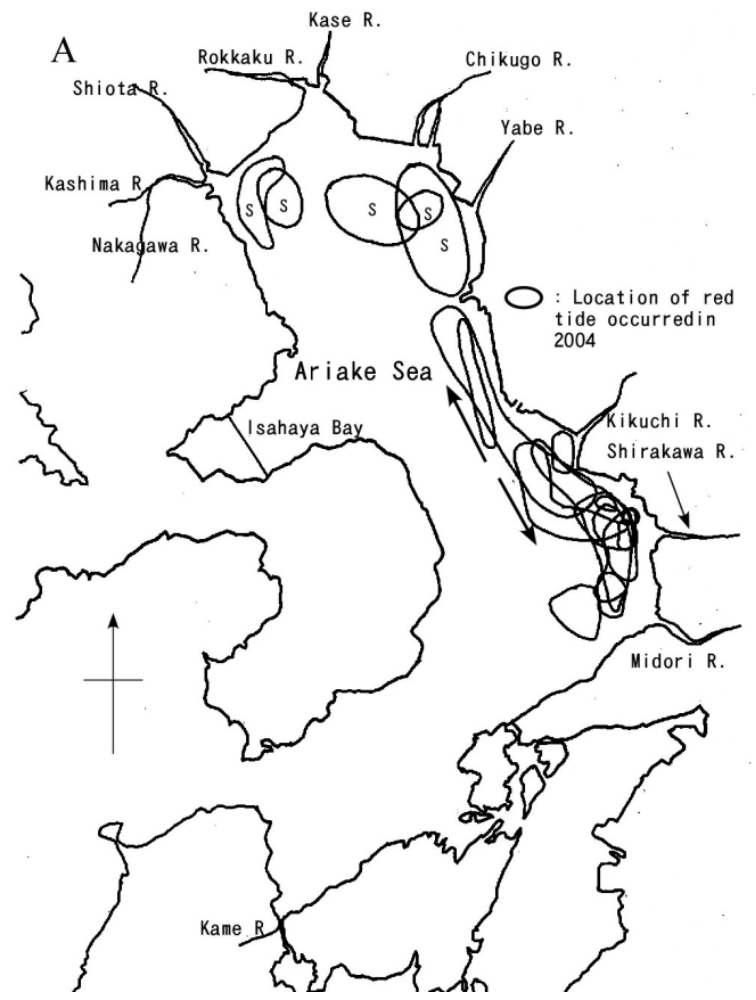

the Yohro River, but the number of red tide occurrences didn't increase as much as number estimated according to the surface areas of the two dams. This may be because the Naramata Dam was built on upstream of the Sudagai Dam and the Hujiwara Dam, which were already completed on the Tone River. It is thought that a dam constructed upstream or downstream from where another dam was already built brings about a smaller number of red tide occurrences than estimated from its surface area.

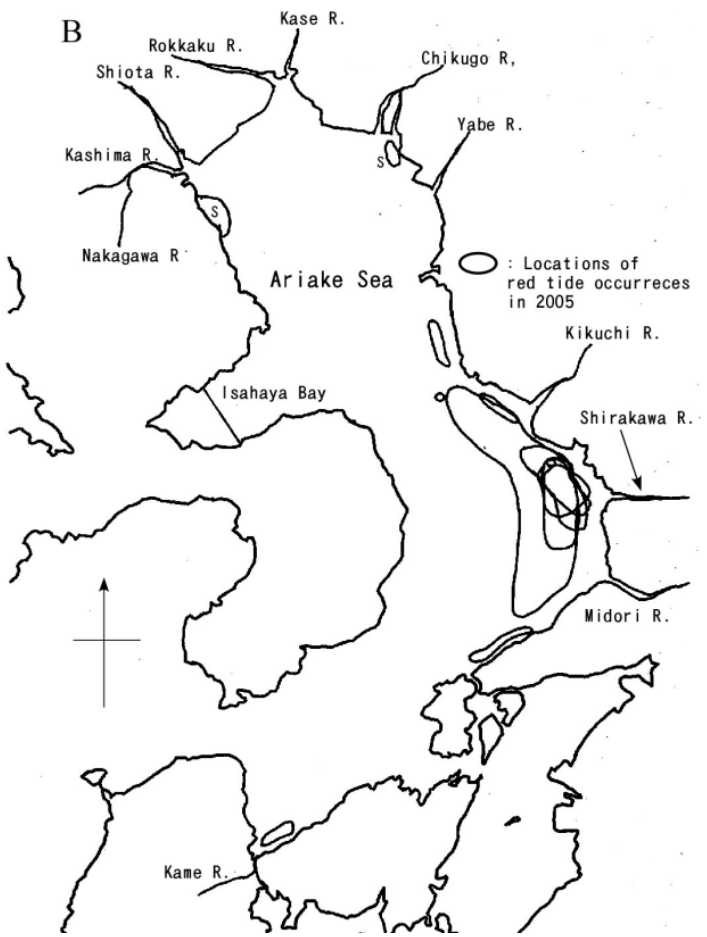

Figure 3. Locations of red tidesobserved in the Ariake Sea. The letter s indicat es a redtide that was est imat ed to be brought about by the dam complet edon the Shiota River in 2001. The letters A and B indicatethe locations of red tide occurrences in 2004 (A) and 2005 (B)

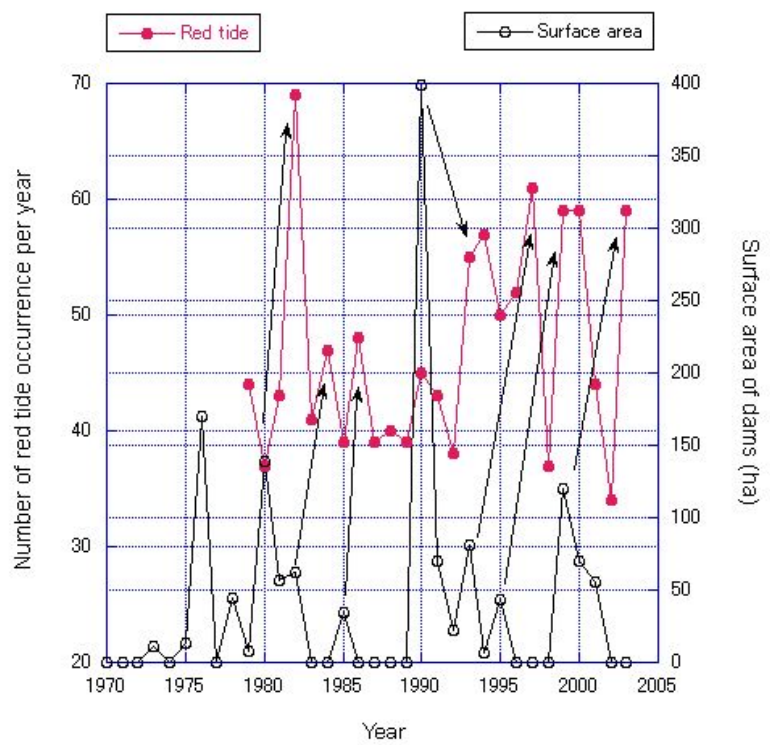

Figure 4. The relationship between the number of red tide occurrences per year in Tokyo Bay and the surface area of dams built on the river flowing into Tokyo Bay. Arrows show the correlations between dam construction and the number of red tide occurrences 
The Nagara Dam was built in 1993 on the Murata River and the dam completion brought about red tides 3-4 years later. In 1995, two dams were built. The Shimagawa Dam with a 32-ha surface area was completed on the upper Tone River and increased the number of red tide occurrences 4 years later in Tokyo Bay. The Urayama Dam with a 120-ha surface area was built on the Arakawa River in 1999 and brought about a red tide 4 years later.

The locations of red tide occurrences in Tokyo Bay are shown in Figure 5. Data of locations of red tide occurrence in Tokyo Bay are reported in detail by the Environmental Bureau of the Tokyo Metropolitan Government and also reported in part by Yokohama City. However, no information about the locations of red tide occurrences was provided by Chiba Prefecture. Thus, perfect information about the locations of red tide occurrences in Tokyo Bay was not obtained. However, it is clear that red tides occurred offshore from the estuary of the Arakawa River in 2003.

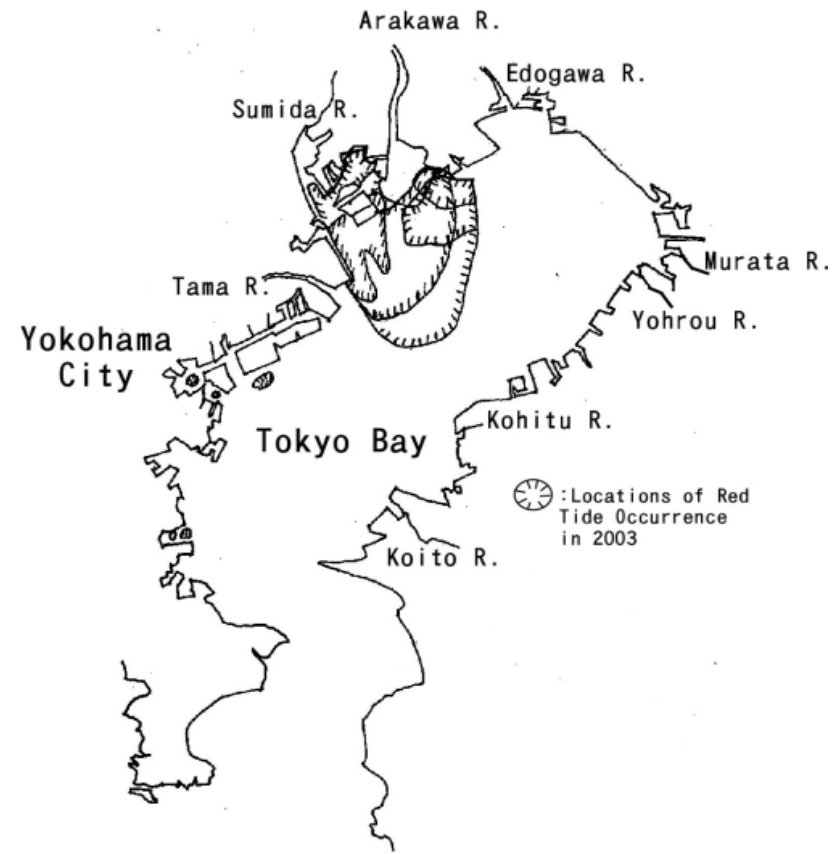

Figure 5. Locations of red tides observed in Tokyo Bay in 2003. The Tokyo Metropolitan Govemment and Yokohama City researched red tide occurrences and reported the locations of red tide occurrences

In 1999, the Urayama Dam with a 120-ha surface area and in 2001, the Goukaku Dam with a 56-ha surface area were completed on the Arakawa River. From the results above, it is thought that these dams brought about red tides in the estuary of the Arakawa River and offshore from Yokohama City in 2003 (Fig. 5). In 2000, the Katakura Dam with a surface area of 70 ha was completed in the Kohitu River of Chiba Prefecture. It is thought that red tides were brought about in Tokyo Bay by the Katakura Dam completion, especially near the seashore of Chiba Prefecture and near the estuary of the Kohitu River. However, the related information could not be obtained.

\subsection{Ise Bay}

The correlation between dam surface area and the number of red tide occurrences in Ise Bay is shown in Figure 6. In 1976, two dams were built. The Iwaya Dam with a 426-ha surface area was built on the Kiso River. The Nakazato Dam with a 130-ha surface area was built on the Innben River. These two dams were considered to bring about the red tides observed in 1979 in Ise Bay. In 1980, three dams were completed. The biggest one of these three dams is Kuroda Dam with an 80-ha surface area. It was built on the Yahagi River, which flows into Mikawa Bay (Ise Bay usually includes Mikawa Bay). Three or four years later, these three completed dams increased the number of red tide occurrences in Ise Bay. In 1985, the Huwa Dam was built. It has a 93-ha surface area and brought about a red tide 5 years later. The Akikawa Dam with a 158-ha surface area was constructed and completed in 1990 on the Kiso River. It was considered to increase the number of red tide occurrences in 1995. The Misokawa Dam was built in 1996 on the Kiso River and its surface area is 135 ha. It is considered to have caused red tides in 1998. In 2001, the Ohshima Dam with a 50-ha surface area was built and increased the number of red tide occurrences 2 years later. The Ohshima Dam is located on the Toyo River, which flows into Mikawa Bay. In 2007, the Tokuyama Dam was built on the Ibi River. The Tokuyama Dam is a huge dam with a surface area of 1300 ha. However, the Tokuyama Dam is located $3 \mathrm{~km}$ upstream from the Yokoyama Dam that was built in 1964. As a result of this situation, which was also seen in Tokyo Bay, the Tokuyama Dam did not increase the number of red tide occurrences in Ise Bay as much as the number estimated from its surface area.

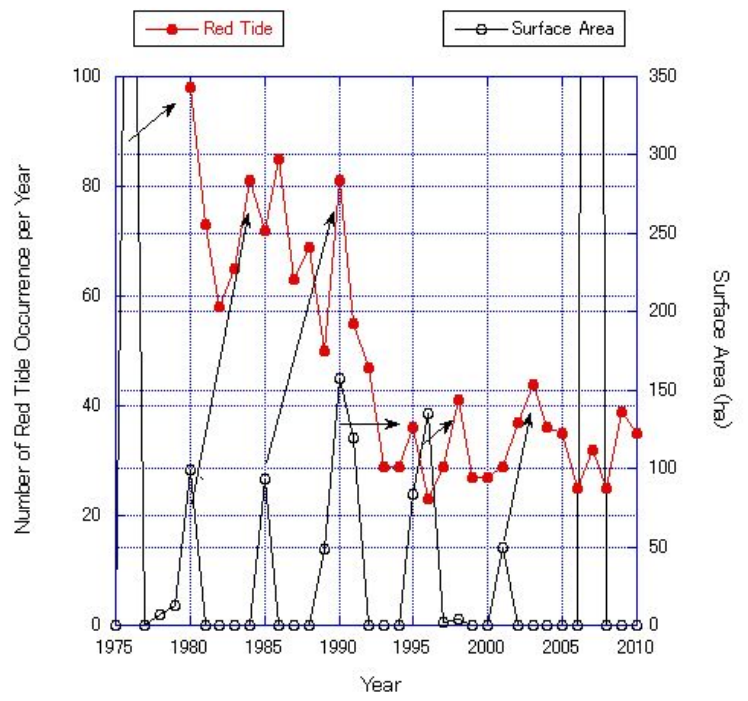

Figure 6. The relat ionship bet ween the number of red tide occurrences per year in Ise Bay and the surface area of dams built on the river flowing into Ise Bay. Arrows show the correlations between dam construction and the number of red tide occurrences 

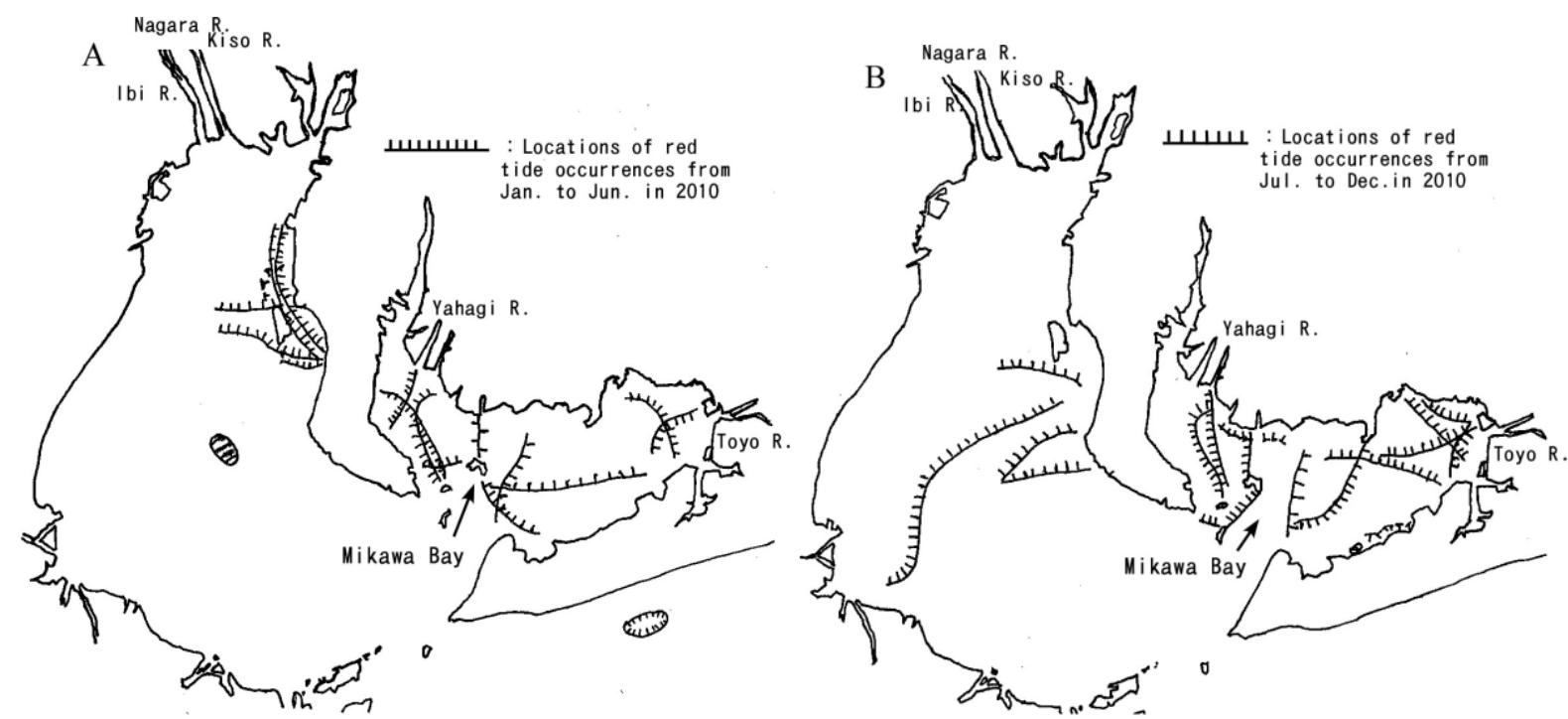

Figure 7. Locations of redtide occurrences observed in Ise Bay in 2010. The letters A and B indicate the locat ions of red tide occurrences from January to June (A) and from July to December (B) in 2010

The locations of red tides observed in Ise Bay in 2010 are shown in Figure 7. No large dam was constructed between 1997 and 2000 on rivers that flow into Ise Bay. The Misokawa Dam was built on the Kiso River in 1996 and the Ohshima Dam was completed on the Toyo River in 2001. From the results above, it is considered that the red tides that are shown in Figure 7 were brought about by the construction and completion of the Oshima Dam. It is also thought that the red tides recorded in the sea near the estuary of the Yahagi River, also shown in Figure 7, were brought about by dams built on the Yahagi River in 1980 and 1990. It is considered that the Misokawa Dam brought about red tides in Ise Bay but not Mikawa Bay.

\subsection{Osaka Bay}

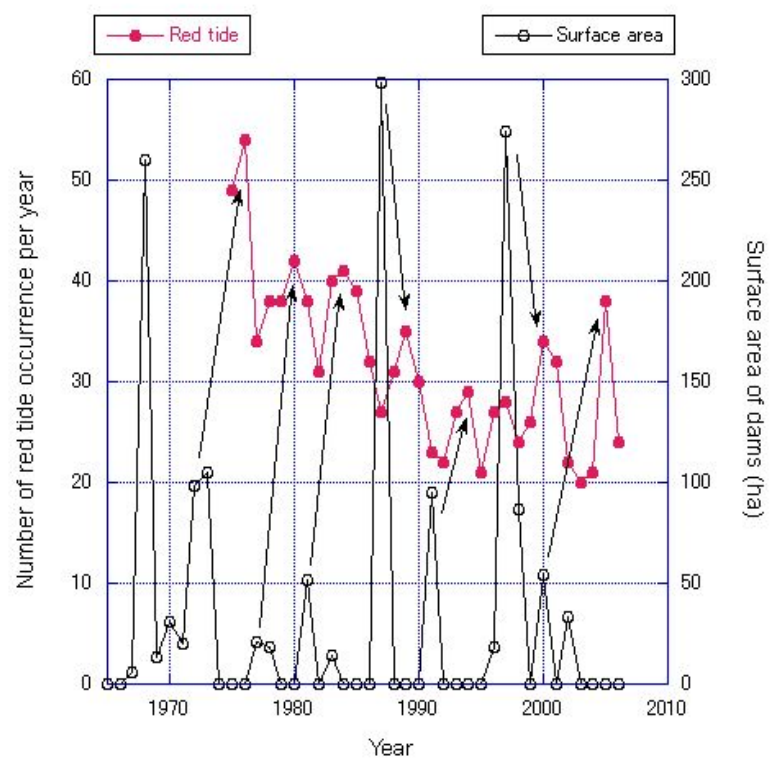

Figure 8. The relationship between the number of red tide occurrences in Osaka Bay and the surface area of dams built on the river flowing into Osaka Bay. Arrows show the correlations between dam construction and the number of red tide occurrences
The Takayama Dam, Eigenji Dam, and Murou Dam brought about red tides observed in 1976 (Fig. 8). In 1968, the Takayama Dam was built on the Kizu River, which is a branch of the Yodo River. The Eigenji Dam was built on the Echi River, a branch of the Yodo River, in 1972 and the Murou Dam was built on the Kizu River in 1973.

Similarly, da ms built in 1977-1978 brought about red tides observed in 1980. The Takihata Dam with a 52-ha surface area was built on the Yamato River in 1981 and brought about the red tides seen in 1983-1985. In 1987, three dams were completed. The Aono Dam built on the Muko River is the biggest of these three dams with a surface area of 215 ha. This dam increased the number of red tide occurrences in 1989. However, its number of red tide occurrences was not large, although the reason is unclear. The Munome Dam with a surface area of 95 ha was constructed and completed on the Kizu River in 1991. This dam increased the number of red tide occurrences3 years after its completion. The Hiyosi Dam with a surface area of 274 ha was built on the Katura River in 1997. This dam brought about red tides in 2000. However, its number of red tide occurrences was not as large as the number estimated from its surface area because the Hiyosi Dam was constructed downstream fro m the Segi Dam, which was built in 1951. In this situation, which was also seen in Tokyo Bay, the number of red tide occurrences does not increase as much as estimated from the dam surface area. Two dams were built on the Kizu River in 2000 and the total surface area of the two dams is 54 ha. These two dams brought about the red tides observed in 1995.

The locations of red tide occurrence in Osaka Bay and Kii Channel in 1960 are shown in Figure 9. From 1950 to 1960, a few dams were constructed on rivers that flow into Osaka Bay and Kii Channel. The Segi Dam with a 48-ha surface area and the Yasugawa Dam with a 50-ha surface area were built on branches of the Yodo River in 1951. Red tide occurrences near the estuary of the Yodo River are shown in Figure 9. In 1953, the Matu-ogawa Dam with a 59-ha surface 
area was built on the Yoshino River of Tokusima Prefecture and red tide occurrence was recorded at an estuary of that river. In 1956, the Chou-anguchi Dam with a 224-ha surface area was built on the Naka River of Tokusima Prefecture and red tides occurred at an estuary of that river.

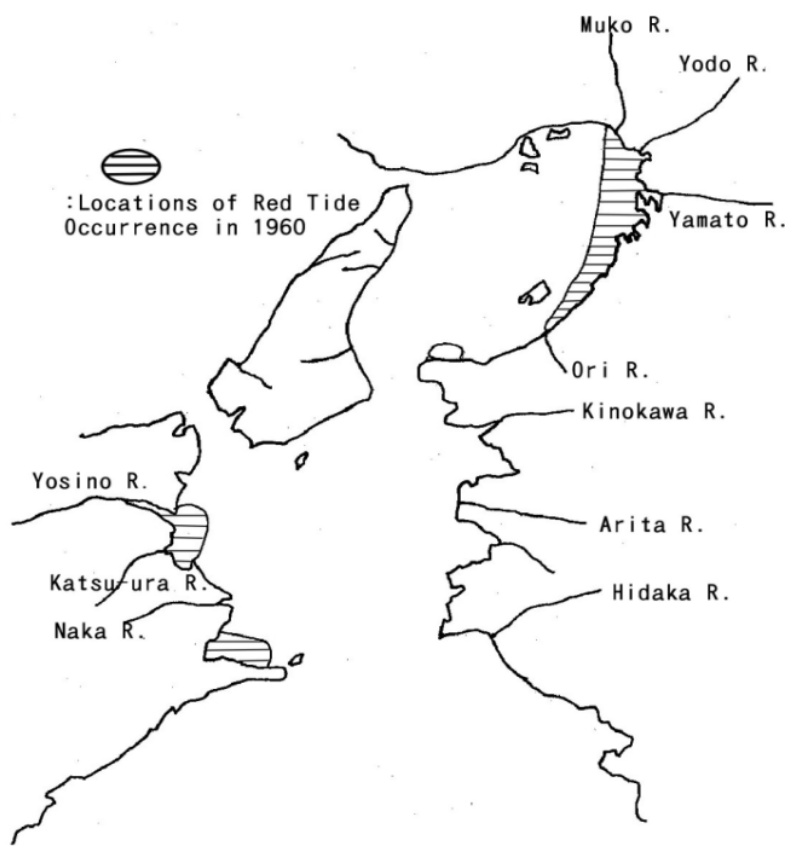

Figure 9. Locat ions of red tide occurrencesobserved in Osaka Bay and Kii Channel in 1960

A typical graph showing the relationship between dam construction and the number of red tide occurrences in a bay is shown in Figure 10. In 1968, a large dam with a 429-ha surface area was built and 7 years later, the number of red tide occurrences increased. After that, the number decreased instantly. In 1977, the number increased again as a result of dam construction in 1972. After 1977, the number decreased again and increased in 1984 from the construction of a dam completed in 1982.

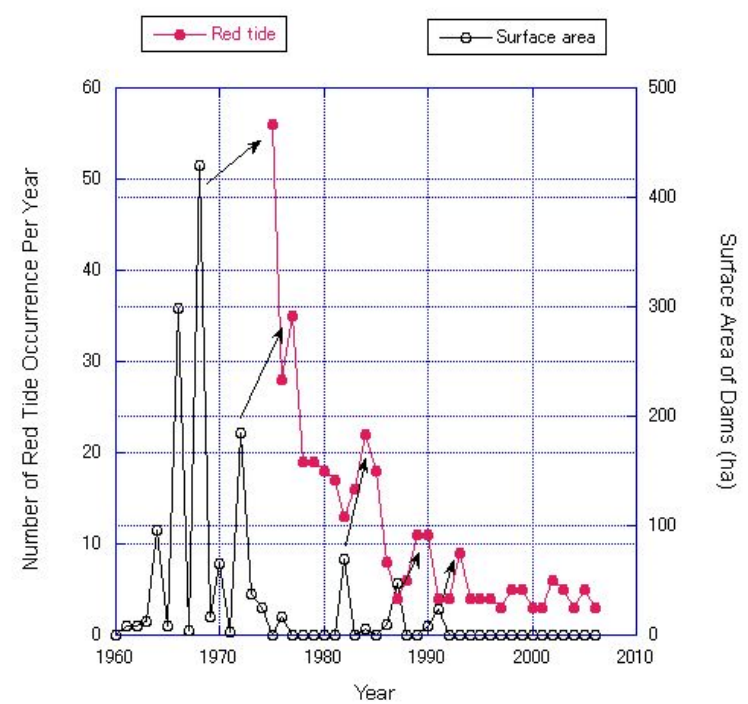

Figure 10. Arrows show the correlations bet ween dam construction and the number of red tide occurrences from 1960 to 2006
It is supposed that the time that elapses from the completion of a dam until the first red tide occurs depends mainly on the dam volume and the upstream flow, because only after a dam is filled with river water, can the river water overflow. When a river flows into a dam, rocks, stones, and sand that are carried by the river precip itate to the bottom of the dam. Particles smaller than sand, such as those of silt and clay, are able to overflow the dam. Those small particles are thought to be the source of red tide after water reaches the bay.

Honjo and Hanaoka researched the constituents of the bottom mud of the seas where red tide occurred and its bottom mud caused an acceleration effect. As a result, they reported that sea bottom mud had an effect on the growth of Heterosigma sp., which is a red tide flagellate[12,13].

Red tide is thought to be brought about by eutrophication. When elemental nutrients such as nitrogen and phosphorus are carried to the sea or lakes by rivers or sewers, planktons can utilize these nutrients. As a result, a great increase in plankton is often seen. This phenomenon is called red tide.

Because all of the mouths of the four bays discussed in this report are narrow, there is little or no tidal current influence from the open sea on the four bays. In these bays, the ebb and flow of the tide is important and dissolved compounds or substances are thought to flow and beco me easily diluted by this tidal current. Considering this condition, it is assumed that there is little time for algae to grow and become red tide.

On the other hand, muddy soil, which is composed of silt and clay, precipitates in the estuary of the dammed river and becomes a layer of soil at the bottom of bays. When the particle size of the soil involved in a river becomes increasingly small, particles are able to be carried a great distant from an estuary and as they precipitate in a bay, they make a fan form in the bottom of that bay.

This soil layer is not moved as easily as dissolved nutrients and can maintain its layer formation. The layer of soil is thought to contain nutrients that stimulate the growth of algae, causing red tide. Thus, muddy soil is considered to be a primary contributor to eutrophication.

\section{Conclusions}

Dam construction appears to influence the occurrences of red tide in the bays downstream from the dams.

Red tide tended to occur in four bays of Japan a few years after dams were built on rivers that flow into the four bays. The numbers of red tide occurrences in these bays were almost proportional to the surface areas of the constructed dams. The red tide occurrences were located at the estuaries of the rivers on which the dams were built.

From these facts, it appears that algae grow and accumulate in the muddy soil that precipitates in the bay and become red tide.

\section{ACKNOWLEDGEMENTS}


I would like to thank the facilities that created websites offering various data of red tides: The Japan Dam Foundati on; Japan Fisheries Resource Conservation Association, Seikai National Fisheries Research Institute; Kanto Regional Development Bureau, Ministry of Land, Infrastructure, Transport, and Tourism; Environmental Bureau of Tokyo Metropolitan Government (TMG); Environmental Institute of Yokohama City; Port and Airport Department, Chubu Regional Bureau, Ministry of Land, Infrastructure, and Transport; Aichi Prefectural Fisheries Experimental Station; and Air and Water Environment Management Division, Ministry of the Environ ment.

\section{REFERENCES}

[1] Trainer, V. L., Adams, N. G., Bill, B. D., Stehr, C. M., Wekell, J. C., Moeller, P., Busman, M., Woodruff, D., 2000, Domoic acid production near California coastal upwelling zones, June 1998. Limnol Oceanogr, 45(8), 1818-1833.

[2] Adams, N. G., Lesoing, M., Trainer, V. L., 2000, Environmental conditions associated with domoic acid in razor clams on the Washington coast. J Shellfish Res 19(2), 1007-1015.

[3] The Japan Dam Foundation. http://damnet.or.jp/

[4] Japan Fisheries Resource Conservation Association. http://ay .fish-jfrca.jp/ariake/gn/index. asp
[5] Seikai N ational F isheries Research Institute. http://ay.fish-jfr ca.jp/akashio/ariake/map_heimen.asp

[6] Kanto Regional Development Bureau, Ministry of Land, Infrastructure, Transport, and Tourism.http://www.tbeic.go.j $\mathrm{p} /$ kanky o/gy ogy o.asp

[7] Environmental Bureau of Tokyo Metropolitan Government. http://www.kanky o.metro.tokyo.jp/water/toky o_bay/red_tide /index.html

[8] Environmental Institute of Yokohama City. http://www.city. yokohama.lg.jp/kankyo/mamoru/kenkyu/

[9] Port and Airport Department, Chubu Regional Bureau, Ministry of Land, Infrastructure, and Transport. http://www.i sewan-db.go.jp/suruga-kanky o/B1b.asp

[10] Aichi Prefectural Fisheries Experimental Station. http://www .pref.aichi.jp/suisanshiken/

[11] Air and Water Environment Management Division, Ministry of the Environment. http://www.env.go.jp/water/heisa/heisa_ net/index.html

[12] Honjo, T. and Hanaoka, T., 1973, Studies on the mechanisms of red tide occurrence in Hakata Bay. II. General features of the red tide flagellate Heterosigma sp., Bull. Plankton Soc. Japan, 19(2), 17-23.

[13] Honjo, T and Hanaoka, T., 1974, Studies on the mechanisms of red tide occurrence in Hakata Bay. III. The characteristics of effective bottom mud and its geographical distribution pattern. Bull. Plankton Soc. Japan, 20(2), 34-38. 